\title{
The Alkaline Dissolution Rate of Calcite
}

\author{
Jean Colombani* \\ Institut Lumière Matière; Université de Lyon; Université Claude Bernard Lyon 1; CNRS UMR \\ 5306; Domaine scientifique de la Doua, F-69622 Villeurbanne, France \\ E-mail: Jean.Colombani@univ-lyon1.fr
}

*To whom correspondence should be addressed 


\section{SUPPORTING INFORMATION}

We present here the details of the processing of the data used in the article for each of the published experiments.

\section{Under-saturation}

In the articles, in the best cases, under-saturation is given under the form: $\left[\mathrm{Ca}^{2+}\right]^{1 / 2}\left[\mathrm{CO}_{3}^{2-}\right]^{1 / 2}$ (with $[\mathrm{X}]$ the concentration of species $\mathrm{X}), a_{\mathrm{Ca}^{2+}} a_{\mathrm{CO}_{3}^{2-}}$ (with $a_{\mathrm{X}}$ the activity of species $\left.\mathrm{X}\right), \log (Q / K)$ (with $Q=a_{\mathrm{Ca}^{2+}} a_{\mathrm{CO}_{3}^{2-}}$ the ionic activity product and $K$ the solubility product of calcite), undersaturation $\Omega=Q / K$, chemical affinity $A=-R T \log \Omega$ ( $R$ stands here for the gas constant and $T$ for temperature) or Gibbs free energy $\Delta G=-A$. In the worst cases, nothing is indicated, 'far from equilibrium' or 'close to equilibrium' conditions being sometimes mentioned.

Here, we have made the choice, for heuristic reasons, to express all dissolution rates as a function of $\Omega^{1 / 2}=a / a_{\text {sat }}, a=Q^{1 / 2}=\left(a_{\mathrm{Ca}^{2+}} a_{\mathrm{CO}_{3}^{2-}}\right)^{1 / 2}$ being the mean ionic activity of $\mathrm{Ca}^{2+}$ and $\mathrm{CO}_{3}^{2-}$ and $a_{\text {sat }}=K^{1 / 2}$ the saturation mean ionic activity.

The solubility product of calcite is $K=10^{-8.48} \mathrm{~mol}^{2} / 1^{2}$. From here on, $R$ is the dissolution rate.

\section{Boundary layer analysis}

To be able to achieve the computation of Eq. (4), the value of $\delta$ is needed for each device. This quantity is well known in rotating disk experiments: $\delta=1.61 D^{1 / 3} v^{1 / 6} \omega^{-1 / 2}$ with $v$ the kinematic viscosity of the solution and $\omega$ the angular velocity of the disk. For batch, mixed flow and fluidized bed experiments, we have considered that the solvent forms a layer as if flowing past a plane plate: $\delta=(2 \pi / 0.244)^{1 / 3} v^{1 / 6} v^{-1 / 2} D^{1 / 3} l^{1 / 2}$ with $v$ the bulk liquid velocity and $l$ the length of the dissolving solid. ${ }^{1}$ We have computed $v$ from $v=c L \omega$ where $c$ is a geometrical parameter, which was chosen as $0.3, L$ the length of the stirrer, estimated as $4 \mathrm{~cm}$, and $\omega$ the stirring rotation rate.

In the particular case of the flow cells used in the dissolution measurements by atomic force 
microscopy (AFM), the complex geometry of the cell and the constant motion of the tip induces a re-mixing that hinders the development of the boundary layer, and reduces the mass transport influence. We have used here a value of $\delta$ estimated from a finite element method simulation of the flow inside an AFM cell. ${ }^{2}$

\section{Plummer 78 (batch)}

- L.N. Plummer, T.M.L. Wigley and D.L. Parkhurst, The kinetic of calcite dissolution in $\mathrm{CO}_{2}$ water systems at $5^{\circ}$ to $60^{\circ} \mathrm{C}$ and 0.0 to 1.0 atm $\mathrm{CO}_{2}$, Am. J. Sci., 1978, 278, pp. 179-216.

- $R$ measured in batch reactor by free-drift, in deionized water, stirred at $800 \mathrm{rpm}$.

- Temperature $=25^{\circ} \mathrm{C}, \mathrm{pCO}_{2}=10^{-3.5} \mathrm{~atm}$.

- Powder with $0.3 \mathrm{~mm}$ grains, geometric surface area $=96 \mathrm{~cm}^{2} / \mathrm{g}$.

- Powder made from Iceland spar crushed, sieved, washed $10 \mathrm{~s}$ in $\mathrm{HCl}$, then acetone, dried at $100^{\circ} \mathrm{C}$.

- Data in figure 6 for the lower $\mathrm{pCO}_{2}$ under the form $R-k_{1} a_{\mathrm{H}^{+}}=f\left(a_{\mathrm{Ca}^{2+}} a_{\mathrm{HCO}_{3}^{-}}\right)$are converted into the form $R=f\left(a / a_{\mathrm{sat}}\right)$ with $k_{1}=0.047 \mathrm{~cm} / \mathrm{s}, a_{\mathrm{H}^{+}}=10^{-7}, a=\left(K_{2} a_{\mathrm{Ca}^{2+}} a_{\mathrm{HCO}_{3}^{-}} / a_{\mathrm{H}^{+}}\right)^{1 / 2}$ and $K_{2}=10^{-10.38} \mathrm{~mol} / \mathrm{l}$ the equilibrium constant of the $\mathrm{HCO}_{3}^{-}=\mathrm{H}^{+}+\mathrm{CO}_{3}^{2-}$ reaction.

\section{Sjöberg 78 (batch)}

- E.L. Sjöberg, Kinetic and mechanism of calcite dissolution in aqueous solutions at low temperatures, Stockholm Contrib. Geol., 1978, 32, pp. 1-92.

- $R$ measured in batch reactor by free-drift, in aqueous solution of $\mathrm{KCl}$ of ionic strength $I=0.7$ $\mathrm{mol} / \mathrm{l}$, stirred at $4.6 \mathrm{rev} \mathrm{s}^{-1}$.

- Temperature $=20^{\circ} \mathrm{C}, \mathrm{pCO}_{2}=0$.

- Commercial powder with 7-8 $\mu \mathrm{m}$ grains, geometric surface area $=0.37 \mathrm{~m}^{2} / \mathrm{g}$. 
- Data in figure 4 under the form $R=f\left(\left[\mathrm{Ca}^{2+}\right]^{1 / 2}\left[\mathrm{CO}_{3}^{2-}\right]^{1 / 2}\right)$ are converted into the form $R=f\left(a / a_{\text {sat }}\right)$ with $a=\left(\gamma_{\mathrm{Ca}^{2+}}\left[\mathrm{Ca}^{2+}\right]\right)^{1 / 2}\left(\gamma_{\mathrm{CO}_{3}^{2-}}\left[\mathrm{CO}_{3}^{2-}\right]\right)^{1 / 2}, \gamma_{\mathrm{Ca}^{2+}}=0.27$ and $\gamma_{\mathrm{CO}_{3}^{2-}}=0.20$, and $R$ is transformed from $\mathrm{g} \mathrm{m}^{-2} \mathrm{~s}^{-1}$ to $\mathrm{mol} \mathrm{m}^{-2} \mathrm{~s}^{-1}$ with the molar mass $M=100 \mathrm{~g} \mathrm{~mol}^{-1}$.

\section{Rickard 83 (batch)}

- D. Rickard and E.L. Sjöberg, Mixed kinetic control of calcite dissolution rates, Am. J. Sci., 1983, 283, pp. 815-830.

- $R$ measured in batch reactor by $\mathrm{pH}$-stat, in aqueous solution of $\mathrm{KCl}$ of ionic strength $I=0.1$ and $0.7 \mathrm{~mol} / \mathrm{l}$, stirred at an unknown rate.

- Temperature $=25^{\circ} \mathrm{C}, \mathrm{pCO}_{2}=0, \mathrm{pH}=9.8$.

- Unknown powder.

- Data in figure 3 under the form $R=f\left(\left[\mathrm{Ca}^{2+}\right]^{1 / 2}\left[\mathrm{CO}_{3}^{2-}\right]^{1 / 2}\right)$ are converted into the form $R=f\left(a / a_{\text {sat }}\right)$ with $a=\left(\gamma_{\mathrm{Ca}^{2+}}\left[\mathrm{Ca}^{2+}\right]\right)^{1 / 2}\left(\gamma_{\mathrm{CO}_{3}^{2-}}\left[\mathrm{CO}_{3}^{2-}\right]\right)^{1 / 2}, \gamma_{\mathrm{Ca}^{2+}}=0.41$ (for $I=0.1 \mathrm{~mol} / \mathrm{l}$ ) or 0.27 (for $I=0.7 \mathrm{~mol} / \mathrm{l}$ ) and $\gamma_{\mathrm{CO}_{3}^{2-}}=0.40$ (for $I=0.1 \mathrm{~mol} / \mathrm{l}$ ) or 0.20 (for $I=0.7 \mathrm{~mol} / \mathrm{l}$ ), and $R$ is transformed from $\mathrm{g} \mathrm{m}^{-2} \mathrm{~s}^{-1}$ to $\mathrm{mol} \mathrm{m}^{-2} \mathrm{~s}^{-1}$ with the molar mass $M=100 \mathrm{~g} \mathrm{~mol}^{-1}$.

- Note in figure 4 that, to have the results collapse for both ionic strengths, the $\left.R=f\left(\left[\mathrm{Ca}^{2+}\right]^{1 / 2}\left[\mathrm{CO}_{3}^{2-}\right]^{1 / 2}\right)\right)$ curves have to be transformed into $\left.\left(\gamma_{\mathrm{Ca}^{2+}} \gamma_{\mathrm{CO}_{3}^{2-}}\right)^{1 / 2} R=f\left(\left(\gamma_{\mathrm{Ca}^{2+}}\left[\mathrm{Ca}^{2+}\right]\right)^{1 / 2}\left(\gamma_{\mathrm{CO}_{3}^{2-}}\left[\mathrm{CO}_{3}^{2-}\right]\right)^{1 / 2}\right)\right)$.

\section{Rickard 83 (disk)}

- D. Rickard and E.L. Sjöberg, Mixed kinetic control of calcite dissolution rates, Am. J. Sci., 1983, 283, pp. 815-830.

- $R$ measured with a rotating disk, in aqueous solution of $\mathrm{KCl}$ of ionic strength $0.7 \mathrm{~mol} / \mathrm{l}$, at various rotation rates.

- Temperature $=25^{\circ} \mathrm{C}, \mathrm{pCO}_{2}=0, \mathrm{pH}=8.4$. 
- Carrara marble and Iceland spar.

- Data of $R^{-1}$ in figure 5 of Iceland spar are converted in $R$, considering $a=0$.

- Results in Sjöberg \& Rickard, Geochim. Cosmochim. Acta, 1983, 47, pp. 2281-2285, figure 3, and in Sjöberg \& Rickard, Geochim. Cosmochim. Acta, 1984, 48, pp. 485-493, figure 1, are identical to these data, so they have not been added to the corpus.

\section{Sjöberg 85 (disk)}

- E.L. Sjöberg and D.T. Rickard, The effect of added dissolved calcium on calcite dissolution kinetics in aqueous solutions at $25^{\circ} \mathrm{C}$, Chem. Geol., 1985, 49, pp. 405-413.

- $R$ measured with a rotating disk, in aqueous solution of $\mathrm{KCl}$ of ionic strength $0.1 \mathrm{~mol} / \mathrm{l}$, at various rotation rates.

- Temperature $=25^{\circ} \mathrm{C}, \mathrm{pCO}_{2}=0, \mathrm{pH}=8.4$.

- Carrara marble polished with grit size \#600, then washed for a few seconds in $\mathrm{HCl}$, then water.

- Data of $R^{-1}$ in figure 5, without $\mathrm{Ca}^{2+}$, are converted into $R$, considering $a=0$. There is a mistake in the ordinate legend, $10^{-8}$ should be replaced by $10^{-9}$ to be consistent with the other values in the article.

\section{Compton 86 (disk)}

- R.G. Compton, P.J. Daly and W.A. House, The dissolution of Iceland spar crystals: The effect of surface morphology, J. Colloid and Interf. Sci., 1986, 113, pp. 12-20.

- $R$ measured with a rotating disk, in aqueous solution of $\mathrm{KCl}$ of ionic strength $0.3 \mathrm{~mol} / \mathrm{l}$, at various rotation rates.

- Temperature $=25^{\circ} \mathrm{C}, \mathrm{pCO}_{2}=0, \mathrm{pH}=6.1$. 
- Iceland spar cleaved and polished with grit size from 25 to $0.25 \mu \mathrm{m}$.

- Data of $R$ from figure 2 for all grit sizes are used, considering $a=0$.

- As admitted in this article, the data from R.G. Compton and P.J. Daly, J. Colloid Interface Sci., 1984, 101, pp. 159-166, are one order of magnitude higher than these of all other studies, which has led us to discard them.

- The article R.G. Compton and P.J. Daly, J. Colloid Interface Sci., 1987, 115, pp. 493-498, shows the evolution of the calcium concentration versus time, without giving the dissolution rate and under-saturation, therefore it was not possible to incorporate its data in the corpus.

\section{Busenberg 86 (batch)}

- E. Busenberg and L.N. Plummer, A comparative study of the dissolution and crystal growth kinetics of calcite and aragonite, Study in diagenesis, ed. by F.A. Mumpton, U.S. Geological Survey 1986, 1578, pp. 139-168.

- $R$ measured in batch reactor by free-drift, in water, stirred at $260 \mathrm{rpm}$.

- Temperature $=25^{\circ} \mathrm{C}, \mathrm{pH}=6$ (calculated).

- Commercial powder.

- Data of $R$ in figure 9 are used, but $\mathrm{pCO}_{2}$ is unknown, and there is probably a mistake because the rates are $\sim 3$ orders of magnitude lower than all the rates mentioned in this study. Trying to recover the values of the tables of the article, we have corrected the data with a $\times 10^{2.5}$ factor.

- The area-normalization is performed using the BET surface, which unfortunately leads to discard these results. 


\section{Chou 89 (bed)}

- L. Chou, R.M. Garrels and R. Wollast, Comparative study of the kinetics and mechanisms of dissolution of carbonate minerals, Chem. Geol., 1989, 78, pp. 269-282.

- $R$ measured with a fluidized bed in water.

- Temperature $=25^{\circ} \mathrm{C}, \mathrm{pCO}_{2} \leq 10^{-3}$ atm, $\mathrm{pH}$ between 7.4 and 9.7.

- Calcite from Mexico ground, washed rapidly with $\mathrm{HCl}$, then acetone, and dried. Grain size is $300-400 \mu \mathrm{m}$.

- Data in figure 4 under the form $k_{-3}=f\left(a_{\mathrm{Ca}^{2+}} a_{\mathrm{CO}_{3}^{2-}}\right)$ are converted to $R=f\left(a / a_{\text {sat }}\right)$ using $R=k_{1} a_{\mathrm{H}^{+}}+k_{3}-k_{-3} a_{\mathrm{Ca}^{2+}} a_{\mathrm{CO}_{3}^{2-}}$ and $a=\left(a_{\mathrm{Ca}^{2+}} a_{\mathrm{CO}_{3}^{2-}}\right)^{1 / 2}$ with $k_{1}=8.9 \times 10^{-5} \mathrm{~mol} \mathrm{~cm}^{-2}$ $\mathrm{s}^{-1}, k_{3}=6.5 \times 10^{-11} \mathrm{~mol} \mathrm{~cm}{ }^{-2} \mathrm{~s}^{-1}$ and $a_{\mathrm{H}^{+}}=10^{-\mathrm{pH}}$.

\section{Schott 89 (cylinder)}

- J. Schott, S. Brantley, D. Crerar, C. Guy, M. Borcsik and C. Willaime, Dissolution kinetics of strained calcite, Geochim. Cosmochim. Acta, 1989, 53, pp. 373-382.

- $R$ measured in batch reactor with $\mathrm{pH}$-stat, in water, stirred at $220 \mathrm{rpm}$.

- Temperature $=25^{\circ} \mathrm{C}, \mathrm{pCO}_{2} \sim 10^{-3} \mathrm{~atm}$.

- Strained Iceland spar cylinder.

- Data $R$ from Table 3 at $\mathrm{pH}=7.4$ and various strains are used, considering $a=0$.

\section{MacInnis 92 (disk)}

- I.N. MacInnis and S.L. Brantley, The role of dislocation and surface morphology in calcite dissolution, Geochim. Cosmochim. Acta, 1992, 56, pp. 1113-1126. 
- $R$ measured with a rotating disk, in aqueous solution of $\mathrm{KCl}$ of ionic strength $0.7 \mathrm{~mol} / \mathrm{l}$, at rotation rate $1160 \mathrm{rpm}$.

- Temperature $=25^{\circ} \mathrm{C}, \mathrm{pCO}_{2}=0, \mathrm{pH}=8.6$.

- Shtall crystal cleaved, polished with grit size \#600 or not polished, etched in $\mathrm{HCl} 20$ min or not etched, washed in water, strained or not strained, washed in acetone.

- Data of $R$ from table 1 for all sample preparations and under-saturation are used.

\section{MacInnis 92 (microphoto)}

- I.N. MacInnis and S.L. Brantley, The role of dislocation and surface morphology in calcite dissolution, Geochim. Cosmochim. Acta, 1992, 56, pp. 1113-1126.

- $R$ measured by microphotographs after dissolution with a rotating disk, in aqueous solution of $\mathrm{KCl}$ of ionic strength $0.7 \mathrm{~mol} / \mathrm{l}$, at rotation rate $1160 \mathrm{rpm}$, from the widening and deepening of etch pits, and the overall retreat of the mineral surface.

- Temperature $=25^{\circ} \mathrm{C}, \mathrm{pCO}_{2}=0, \mathrm{pH}=8.6$.

- Shtall crystal cleaved, polished with grit size \#600, washed in water and acetone.

- $R=4.9 \times 10^{-10} \mathrm{~mol} \mathrm{~cm}^{-2} \mathrm{~s}^{-1}$ for $\log \Omega=-2.82$ is used.

\section{Dove 96 (AFM)}

- P.M. Dove and F.M. Platt, Compatible real-time rates of mineral dissolution by Atomic Force Microscopy (AFM), Chem. Geol., 1996, 127, pp. 331-338.

- $R$ measured by AFM in a flow cell with water from the velocity and spacing of the atomic steps.

- Temperature $=30^{\circ} \mathrm{C}, \mathrm{pCO}_{2}=0$. 
- Calcite from Mexico.

- $R=10^{-7.0} \mathrm{~mol} \mathrm{~m}^{-2} \mathrm{~s}^{-1}$, considering $a=0$, is used.

\section{Liang 97 (AFM)}

- Y. Liang and D.R. Baer, Anisotropic dissolution at the $\mathrm{CaCO}_{3}$ (101) $)$-water interface, Surf. Sci., 1997, 373, pp. 275-287.

- $R$ measured by AFM in a flow cell with water from the velocity and spacing of the slow and fast atomic steps.

- Temperature $=23^{\circ} \mathrm{C}$.

- Natural calcite.

- $R=2 \times 10^{-10} \mathrm{~mol} \mathrm{~cm}^{-2} \mathrm{~s}^{-1}$, considering $a=0$, is used.

\section{Jordan 98 (AFM)}

- G. Jordan and W. Rammensee, Dissolution rates of calcite (1014) obtained by scanning force microscopy: Microphotography-based dissolution kinetics on surface with anisotropic step velocities, Geochim. Cosmochim. Acta, 1998, 62, pp. 941-947.

- $R$ measured by AFM in a flow cell with water from the velocity and spacing of the slow and fast atomic steps.

- Temperature $=24^{\circ} \mathrm{C}, \mathrm{pCO}_{2} \sim 10^{-3.5}$ atm, $\mathrm{pH}=5.6$ (?).

- Calcite from Chihuahua.

- $R=1.5 \times 10^{-6} \mathrm{~mol} \mathrm{~m}^{-2} \mathrm{~s}^{-1}$, considering $a=0$, is used. 


\section{Shiraki 00 (flow cell)}

- R. Shiraki, P.A. Rock and W.H. Casey, Dissolution kinetics of calcite in $0.1 \mathrm{M} \mathrm{NaCl}$ solution at room temperature: an atomic force microscopic (AFM) study, Aquat. Geochem., 2000, 6, pp. 87-108.

- $R$ measured with a flow cell, in aqueous solution of $\mathrm{NaCl}$ of ionic strength $0.1 \mathrm{~mol} / \mathrm{l}$.

- $\mathrm{pCO}_{2} \leq 10^{-5}$ atm, $\mathrm{pH}$ from 7.6 to 10.0 , ambient temperature.

- Calcite from Chihuahua cleaved.

- Data of $R$ in table 1 for various $\log (Q / K)$ and $\mathrm{pH}$ between 7.6 and 10.0 are used, with $a / a_{\text {sat }}=(Q / K)^{1 / 2}$.

\section{Shiraki 00 (AFM)}

- R. Shiraki, P.A. Rock and W.H. Casey, Dissolution kinetics of calcite in $0.1 \mathrm{M} \mathrm{NaCl}$ solution at room temperature: an atomic force microscopic (AFM) study, Aquat. Geochem., 2000, 6, pp. 87-108.

- $R$ measured from the velocity and spacing of the slow and fast atomic steps in a flow cell, in aqueous solution of $\mathrm{NaCl}$ of ionic strength $0.1 \mathrm{~mol} / \mathrm{l}$.

- $\mathrm{pCO}_{2} \leq 10^{-5}$ atm, $\mathrm{pH}$ from 7.6 to 10.0 , ambient temperature.

- Calcite from Chihuahua cleaved.

- Data of $R$ in figure 8 for various $\log (Q / K)$ and $\mathrm{pH}$ between 7.6 and 10.0 are used, with $a / a_{\mathrm{sat}}=(Q / K)^{1 / 2}$.

\section{Arvidson 03 (VSI)}

- R.S. Arvidson, I.E. Ertan, J.E. Amonette and A. Lüttge, Variation in calcite dissolution rates: a fundamental problem?, Geochim. Cosmochim. Acta, 2003, 67, pp. 1623-1634. 
- $R$ measured from the overall vertical retreat of the surface by VSI after dissolution in a flow cell in an aqueous solution of $\mathrm{NaHCO}_{3}$ and $\mathrm{Na}_{2} \mathrm{CO}_{3}$ of ionic strength $4,4 \mathrm{mmol} / \mathrm{l}$.

- Temperature $25^{\circ} \mathrm{C}, \mathrm{pCO}_{2}=10^{-3.41}$ atm, $\mathrm{pH}=8.8$.

- Cleaved calcite.

- Datum $R=10^{-11.0} \mathrm{~mol} \mathrm{~cm} \mathrm{c}^{-2} \mathrm{~s}^{-1}$, considering $a=0$, is used.

- As the aqueous solution is enriched in $\mathrm{CO}_{2}$ by the dissolved salts, this experiment has to be discarded.

\section{Duckworth 04 (flow cell)}

- O.W. Duckworth and S.T. Martin, Dissolution rates and pit morphologies of rhombohedral carbonate minerals, Am. Mineral., 2004, 89, pp. 554-563.

- $R$ measured with a flow cell, in aqueous solution of ionic strength $35 \mathrm{mmol} / \mathrm{l}$.

- $\mathrm{pCO}_{2}=0$, ambient temperature, $\mathrm{pH}$ between 6 and 11 .

- Cleaved calcite.

- Datum $R=10^{-5.6} \mathrm{~mol} \mathrm{~m}{ }^{-2} \mathrm{~s}^{-1}$, constant for $\mathrm{pH}$ from 6 to 11 , considering $a=0$, is used.

\section{Vinson 05 (VSI)}

- M.D. Vinson and A. Lüttge, Multiple length-scale kinetics: an integrated study of calcite dissolution rates and strontium inhibition, Am. J. Sci., 2005, 305, pp. 119-146.

- $R$ measured from the overall vertical retreat of the surface by VSI after dissolution in a flow cell in an aqueous solution of $\mathrm{NaCl}$ of ionic strength $4,4 \mathrm{mmol} / \mathrm{l}$.

- Temperature $22^{\circ} \mathrm{C}, \mathrm{pCO}_{2}=10^{-3.5}$ atm, $\mathrm{pH}>8.5$. 
- Cleaved spar.

- Datum $R=10^{-10.56} \mathrm{~mol} \mathrm{~cm}^{-2} \mathrm{~s}^{-1}$ for $\left[\mathrm{Sr}^{2+}\right]=0$ in $\mathrm{NaCl}$ aqueous solution in figure 5, considering $a=0$, is used.

\section{Cubillas 05 (mixed)}

- P. Cubillas, S. Köhler, M. Prieto, C. Chairat and E.H. Oelkers, Experimental determination of the dissolution rates of calcite, aragonite and bivalves, Chem. Geol., 2005, 216, pp. 59-77.

- $R$ measured with a mixed reactor (flow cell with stirring at 500 to $700 \mathrm{rpm}$ ) in diluted $\mathrm{HCl}$.

- Temperature $25^{\circ} \mathrm{C}, \mathrm{pH}=4$ at entrance, and 5.1 to 9.8 at exit, atmospheric $\mathrm{pCO}_{2}$.

- Powder with grains of size 1 to $1.5 \mathrm{~mm}$, washed with ethanol, of geometric surface area 17.8 $\mathrm{cm}^{2} \mathrm{~g}^{-1}$.

- Data of $R$ from table 3 normalized by the geometric surface area as a function of the affinity $A$, which is converted via $a / a_{\mathrm{sat}}=\left(10^{-\frac{A}{R T}}\right)^{1 / 2}$.

\section{Pokrovsky 05 (disk)}

- O.S. Pokrovsky, S.V. Golubev and J. Schott, Dissolution kinetics of calcite, dolomite and magnesite at $25^{\circ} \mathrm{C}$ and 0 to 50 atm $p \mathrm{CO}_{2}$, Chem. Geol., 2005, 217, pp.239-255.

- $R$ measured with a rotating disk, at a rotation rate of $158 \mathrm{rpm}$, in an aqueous solution of $\mathrm{NaCl}$ of ionic strength $0.01 \mathrm{~mol} / \mathrm{l}$.

- Temperature $25^{\circ} \mathrm{C}, \mathrm{pCO}_{2}=0, \mathrm{pH}=7$ to 8 .

- Cleaved Iceland spar.

- Datum $R=3.60 \times 10^{-11} \mathrm{~mol} \mathrm{~cm}^{-2} \mathrm{~s}^{-1}$ for $\mathrm{pH}=7$ to 8 in table 1 , considering $a=0$, is used. 


\section{Xu 12 (mixed)}

- J. Xu, C. Fan and H.H. Teng, Calcite dissolution kinetics in view of Gibbs free energy, dislocation density, and $\mathrm{pCO}_{2}$, Chem. Geol., 2012, 322-323, pp. 11-18.

- $R$ measured with a mixed reactor (flow cell with stirring at 600 to $800 \mathrm{rpm}$ ) in aqueous solution of $\mathrm{NaHCO}_{3}$ and $\mathrm{CaCl}_{2}$.

- Temperature $25^{\circ} \mathrm{C}, \mathrm{pCO}_{2}=0$ or atmospheric, unknown $\mathrm{pH}$.

- Powder with grains of size 1 to $2 \mathrm{~mm}$ (the other samples are not used because their rate is normalized by their BET surface area).

- Data $R=f(\Omega)$ in figure 3 are converted into the form $R=f\left(a / a_{\mathrm{sat}}\right)$ via $a / a_{\mathrm{sat}}=\Omega^{1 / 2}$.

\section{Experiments of Dreybrodt et al.}

In the following articles, among others:

- U. Svensson and W. Dreybrodt, Chem. Geol., 1992, 100, 129-145,

- W. Dreybrodt, J. Lauckner, L. Zaihua, U. Svensson and D. Buhmann, Geochim. Cosmochim. Acta, 1996, 60, pp. 3375-3381,

- Z. Liu and Dreybrodt, Geochim. Cosmochim. Acta, 1997, 61, pp. 2879-2889,

- L. Eisenlohr, K. Meteva, F. Gabrovsek and W. Dreybrodt, Geochim. Cosmochim. Acta, 1999, 63, pp. 989-1002,

the dissolution rate of calcite in aqueous solutions in various configurations is given. Unfortunately, as the main aim of the authors was the investigation of the influence of $\mathrm{CO}_{2}$ on the reaction, all experiments have been performed with $\mathrm{pCO}_{2}>\mathrm{pCO}_{2}^{\mathrm{atm}}$ and had therefore to be discarded. 


\section{Other studies}

- The values of $R$ measured by batch reactor, AFM and VSI in figure 6 of M.E. Smith, K.G. Knauss and S.R. Higgins, Chem. Geol., 2013, 360-361, pp. 10-21, were too dispersed to be processed (more than one order of magnitude for a given $\Omega$ ).

- The results and conclusion of V.M. Truesdale, 2015, Aquat. Geochem., 21, pp. 365-396, have led recently to much discussion, but no curve of the type $R=f\left(a / a_{\text {sat }}\right)$ was given in this work, so it was not possible to include these data in the corpus.

\section{References}

(1) Jousse, F.; Jongen, T.; Agterof, W. A Method to Dynamically Estimate the Diffusion Boundary Layer from Local Velocity Conditions in Laminar Flows. Int. J. Heat Mass Transfer 2005, 48, 1563.

(2) Gasperino, D.; Yeckel, A.; Olmsted, B.; Ward, M.; Derby, J. Mass Transfer Limitations at Crystallizing Interfaces in an Atomic Force Microscopy Fluid Cell: A Finite Element Analysis. Langmuir 2006, 22, 6578-6586. 